\title{
The Arom of Islamization of Java in The Literature of Pesantren: Study of The Rahman Faithur Book by K.H. Sholeh Darat
}

\author{
Muhammad Abdullah ${ }^{1}$, Mudjahirin Thohir ${ }^{2}$, and Rukiyah ${ }^{3}$ \\ ${ }^{1}$ Master of Literature Program, Diponegoro University, Semarang, Indonesia \\ ${ }^{2}$ Master of Literature Program, Diponegoro University, Semarang, Indonesia \\ ${ }^{3}$ Master of Literature Program, Diponegoro University, Semarang, Indonesia
}

\begin{abstract}
KH. Shaleh Darat is a cleric figure who has a big share in the spread of Islam on the North Coast of Java, especially in Semarang and its surroundings. His father, KH Umar, was a prominent scholar whom Prince Diponegoro trusted in the Javanese war against the Dutch in the north coast of Java. After receiving religious knowledge from his father, little Pious began to wander, studying from one scholar to another. $\mathrm{KH}$ Syahid Waturaja was recorded (studying fiqh books, such as Fath al-Qarib, Fath Al Mu'in, Minhaj al-Qawim, and Syarb al-Khatib). Kiai Shaleh Darat studied religion with major ulama figures such as KH M Sahid who was the grandson of Shaykh Ahmad Mutamakkin, from Kajen Village, Margoyoso, Pati, Central Java who lived in the Mataram Kartosuro era around the 18th century. By translating many books of fiqh and tasawuf in Javanese, $\mathrm{KH}$ Sholeh Darat conveyed the message of da'wah at the house of the Regent of Demak who was the uncle of R.A. Kartini. From behind the veil, Kartini was amazed by Al-Fatihah's interpretation in Javanese so that Kartini understood. R.A. Kartini urged her uncle to meet KH Sholeh Darat. After meeting, to the kiai, Kartini asked that the Al Quran be translated. At the call of the da'wah and Kartini's request, KH Sholeh Darat translated it using Arabic Pegon. The book is recorded as the world's first translation of the Quran in Javanese. The first book of interpretation in Javanese Arabic Pegon is named Faidhur Rohman. Faithur Rahman's tafsir book is a Javanese interpretation, written the world's first pegon. Together with the manuscript Syarah Al Hikam KH Sholeh Darat Al Faithur Rahman kept by the takmir of the Sholeh Darat Mosque, Dadapsari, Semarang. What is interesting about Faithur Rahman is his translation in the letter Al Fatihah which explains how the belief system and tarekat (the straight path) in Islam. Then what are the characteristics of pious people in the beginning of the letter Al Baqoroh. With this Javanese translation, it finally made it easier for Javanese Muslims to learn Islam. The ease of learning Islam is what gives a wind of harmony in religion.
\end{abstract}

\section{Introduction}

As recorded in history, the success of Islamic da'wah (Islamization) in Java could not be separated from the role of the ulama, who, with their great works, was able to transform 
Islamic values brilliantly. Through the work of this pesantren, Islamic intellectual and thought traditions are passed down from generation to generation, from one generation to the next. It is from this segment that the Indonesian Islamic intellectual network grows and develops. This was especially true in the era of great scholars such as Syeikh Abdus Samad Al-Palembani, Syeikh Abdur Rauf As-Singkili, Syeikh Yusuf Al-Makassari, Hamzah Fansuri, Syamsuddin As-Samatrani, Nuruddin Ar-Raniri, Muhammad Arsyad Al-Banjari, and others. -other until finally the generation of Imam Nawawi Al-Bantani, Kyai Ihsan Jampes, Kyai Saleh Darat (Shalih bin Umar Al-Samarani, w.1321 / 1903), around 17-19 AD. Post-19th century appeared the names of the authors of the book and pesantren literature, such as KH Mahfudz from Tremas who lived and taught in Mecca around the 1900s; Another scholar is KH Ihsan bin Muhammad Dahlan from Jampes Kediri, who wrote the book Siraj Al-Thalibin. In addition, there is a very productive Javanese scholar, KH Bisri Mustofa (father of KH Mustofa Bisri), from Rembang. He wrote more than twenty pesantren works. (see, Azra, 1994: 36; Bruinessen, 1999: 19-20; Daudy, 1983: 35; Baried in Drewes, 1990: vii; Thohari, 1991).

This Islamic intellectual tradition is revealed through the written tradition in Islamic education, thought and culture. That is why traces of Islamic intellectuals appear in classical religious texts containing various Islamic teachings, such as tawhid, tafsir, ahlak, fiqh, and the teaching of Sufism, also known as Sufism pesantren literature (Liaw Yock Fang, 1993: 41- 42). However, it seems that in Indonesia, this literacy tradition has decreased after the triumph of the thought of Imam Nawawi Al-Bantani from Banten, whose works are widely used in India and Middle Eastern countries (Hasan, 1990: 21). Among the factors that influenced the decline of the writing tradition among Indonesian ulama at that time until recently were (1) the stronger influence of the oral tradition, which was institutionalized in the traditions of the Islamic community, so that the kyai or ulama preferred to actualize their knowledge through recitation and lectures. -lecture; (2) the weak ethos of literacy in the tradition of Islamic boarding schools in Indonesia, mainly due to the habit of conducting oral teaching, whether in the form of religious lectures or delivering the yellow book teaching in Islamic boarding schools in a manqul and sorogan, (3) and a shift in the orientation of society from the scientific world to other fields. Such as the world of politics and economics (Dhofier, 1982: 9; Thohari, 1991; Abdullah, 1995: 23; Bruinessen, 1999: 25-26).

The results of the inventory carried out by the Jakarta Central Museum of syi'ir literary works only covered four syi'ir (Soewignjo and Wirawangsa, 1920: 318). However, to date, there appears to be no further research effort recording several syi'ir texts among pesantren. I don't know precisely why research on syi'ir is still in low demand. Perhaps because of the lack of socialization and publication of syi'ir works in general. To answer this problem, it is very important to refine and publish syi'ir texts to consume the academic community and society in general.

The discourse that is currently being questioned is the extent to which classical literary works, including pesantren literary works, can provide moral teaching value or use value and benefit to its readers. To what extent has the classical literary works of pesantren, both in the form of classical texts and syi'ir-syi'ir, have been able to provide ethical education and solutions due to the rampant moral decadence? Of adolescents today. Its strategic value lies in grounding the function of character education in the learning process for students, maturing in the younger generation of readers in the more popular form of creative industries.

This research was conducted to save and preserve the Islamic intellectual heritage in coastal communities, especially as a model of moderate da'wah, by translating and translating the text of the Faithur Rahman Book. The second specific objective is to provide a description, transliteration and translation of Faithur Rahman's text to be read and enjoyed by ordinary readers in studying Islam. The third objective is to reveal and analyze the contents of the text of Faithur Rahman to know the meaning and function of the text in society. 


\section{Research methods}

To support the input of data information, this research will be conducted using the following methods. First, the research method of philology as a classical manuscript research method, namely by the steps of the method of inventory, description, transliteration, translation, and identification of the text of the Kitab Syarah Al-Hikam; Second, the literature review method, and third, the field research method, namely the method of recording data by interviewing historical figures and expert heirs. After that, a focus group discussion (FGD) was held, and research data analysis methods were carried out.

In practice the description of the method can follow the steps in stages as follows:

1. Inventory and identification of Al Hikam texts in Java, most of which are not appreciated by modern society;

2. Identify and describe the text: That is to record and select the physical condition of the Syarah Al Hikam text using an interview approach.

3. Classifying the text, which is very important to do, because it is to get the best text.

4. Text compilation method, which is the collection of the best spoken text which will be used as the selected text.

5. Content analysis and

The literature study method is used to analyze the content, especially those that contain aspects of high religiosity and morality educationally. The discussion on these aspects will be enriched with various references, which refer to ethical and moral teachings as taught in Islamic culture and religion.

\section{Discussion}

His struggle in Islamic religious sciences, $\mathrm{KH}$ Sholeh Darat received valuable input from RA Kartini, especially about the methodology of learning Arabic books into Javanese (pegon letters). When participating in her recitation, KH Sholeh Darat, at the residence of the Regent of Demak, Kartini took the courage to propose that the Al-Quran be translated into Javanese so that it is easy for the layman to understand. Because at that time, many Arabic terms were not widely understood by ordinary Javanese, so many experienced a symptom of a language called paracustie. Even the aqidah teachings of Kanjeng Sunan Kalijaga have undergone a paracustie process, namely the dolanan song Sluku-sluku Bathok.

KH Sholeh's opening sentence in the Book of Faidlurahman is as follows.

"Sebab kerono gegawe wasilah marang barang kang luweh gede iyo iku weruhe

wong akih marang ilmu lan hikmah lan asrar. Ing hale asrar iku asrare Ratu kang agung lan maneh iki ta'jil iku ta'jil ata wal hikam".

This opening sentence is a textual fact from KH Sholeh Darat regarding RA Kartini's anxiety in understanding the secrets of the Qur'an. Kyai Sholeh Darat emphasized that the request to publish part of this interpretation was the request of some of his friends (ikhwan kito fiddin). Islamic da'wah certainly requires contextual preaching material and language. Namely, the provision of material and methods of preaching Islam pays attention to the situation and objectives of the era. KH Sholeh Darat was quite intelligent and responsive in responding to the situation of the Javanese Islamic community. Moreover, some people do not understand Arabic as a source and reference for Islamic studies and preaching.

The following is the text of Syarah Al Hikam by KH Saleh Darat.

"Mangka anuturaken Syekh Ibnu 'Athā'illah waliyullah/ ing alamate wang kang kekanda lan marang liyane Allah kèlawan/ wani pangandikane syaeh iku (min 'alāmati al-i'timādi 'ala al-'amali nuqshanul ar-rijāi 'inda wujudi az-zalali) tègèse setengah saking/ alamate wang kang cecekalan ingatase amale iku kurang/ pangarèp are ping rahmate Allah nalikane tumiba ing dalèm/ kaluputan, kaya 
ma'siate utawa lali marang Allah,/ kaya lamun ngucap atine ba'dane tumiba marang keluputan:/ "uga ingsun wes mesti manjing neraka sebab/ iki ma'siat, lan Allah wes ora ngapura marang ingsun"\% Balik wajib marang kang tumiba marang kaluputan arèp ndepe-ndepel marang Allah ta'ala, lan rumangsaha sira satuhune tumibane/ marang keluputanne iku kèlawan sifat qahare Allah.//"

Meaning:

"Therefore, Shaykh Ibn Atha'illah mentioned the signs of people who rely on other than Allah SWT through his words as follows: min 'alāmati al-i'timādi' ala al'amali nuqshanu ar-rijāi 'inda wujudi az- zalali means: Among the signs that a person relies on the strength of his deeds is a lack of hope for the grace of Allah when something wrong or sin occurs. For example, immorality or forgetting from remembering Allah SWT., That is, when someone's heart says after making a mistake, "I will definitely go to hell because of my sin, and Allah will not forgive my sins." However, people should fall into a sin must draw closer to Allah SWT. and feel that he committed the sin because of the nature of Qahhar (Almighty) Allah SWT."

By translating manuscripts from Arabic into Javanese, such as the Faidhur Rahman Book, Kyai Shaleh wanted to invite and guide Javanese Muslims, who are unfamiliar with Arabic to understand sharia and Islamic teachings and understand the practice of Islam. Thus, Kyai Saleh's preaching ethos was a breakthrough in the methods and Islamization of 18th century Java. Besides translating the book, Faithur Rahman Kyai Shaleh also translated other books, such as Munjiyat, Tafsir Quran, Majmu 'Sharif, etc.

KH Shole Darat including Indonesian scholars who are prolific in writing books. There are many books by KH Sholeh Darat; there are about 14 kiora books, most of which are translated works.

1. Majmu'at Asy-Syari'at al Kifayat lil lay

2. Munjiyat, Methik So Ihya 'Ulumuddin al; Ghazali

3. Syarah Al-Hikam (Summary of Ibn Athoillah's work),

4. Lathaif al-Thoharoh

5. Manasik Al Hajj

6. Tarjamah Sabilul 'ala Jauharah al-Tauhid

7. Faidlurrahman, etc.

8. Syekh'illah

On that occasion, KH Soleh Darat had the opportunity to study religion from his father's friends. Among them are Kyai Hasan Besari, Kyai Syada (Diponegoro's trusted soldier), Kyai Darda, Kyai Murtadho, and Kyai Jamsari (Founder of Kjamsaren Solo Islamic boarding school). Kyai Hasan Besari is Prince Diponegoro's adjutant. One of his grandchildren, KH M. Moenawir, founder of Ponpes Krapyak Jogjakarta, is a student of KH Sholeh Darat. It is even known that $\mathrm{KH}$ Sholeh also studied at $\mathrm{KH}$ Asy'ari (Kyai Guru) from Kaliwungu, Kendal. From the Haramain area, he studied from the following teachers.

1. Syeh Muhammad Al Maqri al Mashri al Makki

2. Syeh Muhammad bin Sulaiman Hasballah

3. Sayyid Ahmad Bin Zaeni Dahlan

4. Syeh Muhammad Salih Az-Zawawi al Makki, and others.

Therefore, in the 19th century Javanese Islamization process, KH Sholeh Darat used an adaptive cultural approach. Namely, the learning approach model in Javanese so that ordinary people understand. This approach is what KH Sholeh Darat did by translating many yellow books into Javanese. This was also done by KH Bisri Mustofa (Gus Mus's father) by compiling the Quranic commentary book, Al-Ibris. KH Sholeh Darat is one of the strongest Sufu scholars in deepening Sufistic values. The ethos of Sufism studies comes from strong sources, Ihya Ulumuddin, Minhajul Abidin, Al-Hikam etc. 
In today's context, when hedonism, materialism, syncretism, hybridity, and liberalism are very lively in our lives, studies with esoteric nuances are needed. KH Sholeh is very concerned about studies that bring the congregation to taqorrub ilallah, making their life orientation only towards Allah - using modern language, oriented to the monotheistic paradigm. This was also done by many great lamas, such as Imam Al Ghozali, Syekh Ab dul Qadir Al Jailani, Syeh Samman, Imam Nawawi Al Bantani, etc. KH Sholeh Darat and his father, KH Umar (who died and was buried in Mecca), became trusted friends of Pangeran Diponegoro to escort and coordinate the jihad fii sabilillah movement in the northern part of Java against Dutch colonialism.

On that occasion, KH Soleh Darat had the opportunity to study religion from his father's friends. Among them are Kyai Hasan Besari, Kyai Syada (Diponegoro's trusted soldier), Kyai Darda, Kyai Murtadho, and Kyai Jamsari (Founder of Kjamsaren Solo Islamic boarding school). Kyai Hasan Besari is Prince Diponegoro's adjutant. One of his grandchildren, KH M. Moenawir, founder of Ponpes Krapyak Jogjakarta, is a student of KH Sholeh Darat.

KH Sholeh Darat's principle of moderation is very evident in the following ways. First, KH Sholeh Darat, in his studies, tried to synthesize the tendencies of Sharia teachings and the teachings of tarekat-natures. This balance was able to bridge the mystical and Javanese teachings of Javanese culture at that time. Second, KH Sholeh Darat was also able to synthesize salaf Islamic teachings in the context of Javanese culture, which at that time had many shades of secretism. This is a beautiful Islamisation approach.

\section{Conclusions}

From the above description, the following conclusions can be drawn.

a. The figure of $\mathrm{KH}$ Soleh Darat is a polite Javanese cleric figure who is able to embody Islamic da'wah in accommodative and persuasive language.

b. The Islamization of Java by KH Soleh Darat through the translation of Arabic books into Javanese is a form of simplification of the da'wah method in Java which respects Javanese traditions and language as the regional language of the coastal Javanese.

c. KH Soleh Darat's model of Islamization with his translation and learning through the AlHikam Book is truly a way of Islamic education which has succeeded in bringing the Javanese Islamic community to develop their Islam.

\section{References}

1. Abdullah, Muhammad. Functional Review of Manakib Syeikh Abdul Qadir Jailani (Thesis) (1986)

2. . "Theology Asy'ariyah Syeikh Nuruddin Ar-Raniri: Study of Durrāt Al-Farā'id" in Literary Studies. No. 25. year XXII (1998) Singkili (1999) . Understanding Wa $¥$ dah Al-Wujūd. Sheikh Abdur Rauf As. Deconstruction of Islamic Boarding School Literature (2009)

4. Treasure of Coastal Literature (2011)

5. Azra, Azyumardi. The Middle East and Archipelago Archipelago Ulama Network XVII -XVIII centuries (1995)

6. . "The Interaction of Islam with the Malay Culture of Borneo" in the Spirit of Islam in National Culture (1986)

7. Baried, Baroroh. Dictionary of Philological Terms (1977) 
8 Introduction to Philological Theory (1987)

9. Basuki, Anhari. Old Literary Research Methods (1989)

10. dkk. Introduction to Philology (2004)

11. Braginsky, V. I. Sufism and Malay Literature, Studies and Texts (1993a)

12. . The System of Classical Malay Literature (1993b)

13. Danandjaja, Djames. Indonesian Folklore (1985)

14. Dhofier, Zamachsyari. Tradition of Pesantren (1982)

15. Djamaris, Edwar. "Philology and the Work of Philological Research" in Language and Literature. Year III Number 1 (1977)

16. . Philological Research Methods (2002)

17. Hadi W.M, Abdul. The Oppressed Sufism, Hermeneutic Studies Against Hamzah Fansuri's works (2001)

18. Indraswara, Suwardi. Javanese folklore (2012)

19. Hermeneutics, Aesthetics, and Religiosity (Literary Essays Sufism and Fine Arts) (2004)

20. Kratz, E.U. "The Editing of Malay Manuscripts and Textual Criticism"in BKI 137.

21. Liaw Yock Fang. History of Classical Malay Literature (book 1) (1978)

22. Simuh. Kejawen Islamic mystical Raden Ngabehi Ranggawarsita: A Study Against Wirid Hidayat Jati Fiber (1988)

$23 . \quad$. Heritage of Islamic Spirituality in Javanese Culture" in The Spirit of Islam in National Culture (1996)

24. Soebardi. "Islam in Indonesia" in Prisma. Extra Number Th VII Jakarta: LP3ES (1976)

25. Teeuw, A. Literature and Literature: An Introduction to Literary Theory (1988)

$26 . \quad$. Indonesia: Between Orality and Literacy (1994)

27. Thohir, Mudjahirin et al. Inventory of Islamic Boarding School Literary Works at Kaliwungu Kendal (1992)

28. Thohari, Hajriyanto. "Tracing the Footsteps of Indonesian Islamic Intellectuals" In Suara Merdeka, February 2 edition. Thing. IV (1990)

29. Wahid, Abdurrahman. "Nahdlatul Ulama and Islam in Indonesia Today" in the Tradition and Awakening of Islam in Southeast Asia (Taufik Abdullah, Ed.) (1989)

30. Hadi WM, Abdul, "Reviving the Prophetic Spirit of Islamic Literature" in UL, MUL QUR'AN. No.3 (1991)

31. Zoetmulder, P.J. Manunggaling Kawula Gusti, Pantheism and Monism In Javanese Suluk Literature: A Philosophical Study (1991) 